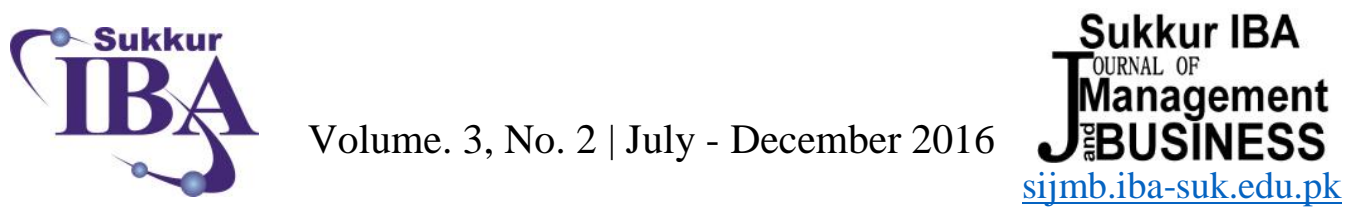

\title{
Financing the Fiscal Deficit in Pakistan: Evidence on Ricardian Equivalence
}

\author{
Neelma Shamsi ${ }^{1}$ \\ The University of Lahore, Sargodha Campus, Pakistan \\ Muhammad Waqas*2 \\ UMR-SADAPT Agroparistech France
}

\begin{abstract}
:
This study investigated the validity of Ricardian equivalence hypothesis in case of Pakistan. Annual time series data from 1978 to 2013 has been used for analysis. Two models have been estimated; structural consumption function and structural saving function. The results of unit root tests explored that all the variables have different order of integration. The results of ARDL co-integration approach verified the existence of a long run relationship among variables for both models. By using OLS, wald test rejects the restrictions on both models and concludes that Pakistan is a non-ricardian economy.
\end{abstract}

Keywords: Ricardian Equivalence Theory, Budget Deficit, Pakistan

\section{Introduction}

Fiscal deficit has become a major problem among developing countries. The objective of stabilization policy in Pakistan is to raise private consumption and reduce fiscal deficit. When government expenditure exceeds from its revenue, there exists fiscal deficit. It is very essential to evaluate the sources to finance this deficit. Government has three ways to finance this deficit: through increasing tax rate, borrowing, and printing money Gumus (2003). Every source has its own consequence on the economy. Therefore, it is very essential to evaluate the effects of financing the deficit through every source. Increase in tax rate or levying new taxes are hard to implement because people don't admire it Bird and Zolt (2003). Printing money leads to inflation Dem, Mihailovici, and Gao (2001).That's why only convenient option left for government is

https://doi.org/10.30537/sijmb.v3i2.97

${ }^{1}$ neelma shamsi@yahoo.com

* Corresponding Author

2 m.waqas@uos.edu.pk

SIJMB | E-ISSN: 2410-1885; P-ISSN: 2313-1217 @ 2016 Sukkur Institute of Business Administration - All rights reserved 
to finance its deficit through borrowing. Lot of work has been done on the effects of financing the deficit from borrowing. Regarding the impact of deficit financing through borrowing, there are two schools of thought: Ricardian and Keynesian.

The concept of Ricardian Equivalence has been presented by Ricardo (1817) which is further expanded by Barro (1974). Ricardian equivalence hypothesis (REH) states that a debt financed tax cut would not increase private consumption as well as aggregate demand because consumers know that they have to pay higher taxes in future after the maturity of the debt. Therefore, they save this extra tax cut and buy bonds because they know that after the majority of debt they would be able to pay higher taxes. Therefore, in case of REH private saving increases while national saving and investment remains unchanged Kazmi and Shabbir (1992). Hence Government's aim to increase consumption and decrease budget deficit is not fulfilled, because consumers are forward looking, and fiscal policy is ineffective in this case. REH is basically having equivalence between taxes and debt. Government either finances her deficit through borrowing or increasing tax rate, both have similar effect on private consumption. REH holds in the presence of certain assumptions like consumers are infinitely lived, rational, perfectly informed and have no saving purpose, consumers face no liquidity constraints and taxes are lump-sum Malengier and Pozzi (2004).

According to Keynesian school of thought, a debt financed tax cut would increase consumption and aggregate demand because consumers assume this tax cut as a blessing and don't think about their future generations because they prefer present to future. They do not consider government bonds as net wealth. In result of tax cut, their private consumption increases while private saving remains unchanged. Hence fiscal policy is effective in Keynesian case Tcherneva (2011).

The present study is an effort to investigate the validity of Ricardian equivalence hypothesis in Pakistan by using the annual data from 1978-2013. We utilized both function, consumption and saving function and tested the hypothesis by utilizing cointegration approach.

The rest of the study is organized as the second part presents the studies that checked the validity of REH. The part three describes the data and methodology. The fourth part explains the results of the study and the last part gives conclusion and presents policy options based on results.

\section{Review of Literature}

Ricardo (1817) first time presented the concept of Ricardian Equivalence. This concept was further expanded by Barro (1974). After that, this topic got so much importance in research. Many other researchers have tried to check the validity of REH. Some of them explained this topic in case of Pakistan and each of them have their own limitations. Di Laurea and Ricciuti (2002) tried to test the deviation from Ricardian equivalence through creating an overlapping generation experiment. The paper consists of three

Sukkur IBA Journal of Management and Business | Volume 3 No. 2 July - December 2016 @ Sukkur Institute of Business Administration 
steps. The first step consists of theoretical model, which is ideal for Ricardian equivalence. Therefore, this accepts the Ricardian Equivalence hypothesis. According to theory, there are two main reasons of rejection of the Ricardian equivalence; presence of liquidity constrained consumers and insecurity about future income. That's why second step included liquidity constrained consumers in the model and third step introduced insecurity of future income in the model. Second and third steps reject the validation of Ricardian equivalence hypothesis. Malengier and Pozzi (2004) explored the validity of Ricardian Equivalence proposition using panel data for the period 19801997.The data is collected for the 19 OECD countries. They construct a nonlinear consumption function with two types of consumers. The consumer who focuses on current income called rule of thumb consumers and the consumers who consider budget limitations of government called permanent income consumers. By using moment conditions, Generalized Method of Moments (GMM) is estimated. One-level and twolevel bootstraps are applied to check this estimator. The results show that in OECD countries, $25 \%$ consumers are rule-of-thumb consumers and remaining $75 \%$ are permanent income consumers. The study concludes that first type of consumers fail to accept the Ricardian Equivalence proposition while second type also rejects the hypothesis if government asks these consumers to consume less and save more as precautionary measure from their permanent income. The study by Cunningham and Harberger (2005) tried to test the validity of Ricardian Equivalence by using Ricardian disposable income. "Ricardian" income of a state refers to the subtraction of net addition to debt and Federal Debt share of the state from standard disposable income. Time series data of income is collected from U.S. States and regression analysis is run. First regression is applied using standard disposable income and then using Ricardian disposable income to check the electricity consumption in different states. Relative price and real income are used as regressers in standard tests while other test adds natural gas price and whether as variables. The results of standard tests show more significant results then later tests and are more preferable.

Afonso (2008) checked the private consumer response to government indebtedness in EU countries. The objective of the paper is to test the existence of debt neutrality hypothesis in EU countries. Debt neutrality hypothesis refer to ineffectiveness of private consumption in response of Government debt polices. The study consists of panel data onto the period 1970-2006 and estimate Euler equation. The paper rejects the existence of debt neutrality hypothesis in EU countries and concludes that private consumption decreases due to high government indebtedness.

Waqas and Awan (2011) explored the validity of Ricardian Equivalence proposition using annual data from Pakistan. A Structural consumption function is estimated for the period 1973-2009. Johansen cointegration approach is applied and finds long run relationships among variables. This paper rejects the existence of REH because fiscal policy is quite efficient in Pakistan. Furthermore, Waqas and Awan (2011) tried to check the existence of REH and causes of its rejection in Pakistan. Engle and Granger and Johansen Co-integration approaches are used to find out the long run relationships

Sukkur IBA Journal of Management and Business | Volume 3 No. 2 July - December 2016 @ Sukkur Institute of Business Administration 
among variables. Generalized method of moment is used for estimation. This paper concludes that REH fails in case of Pakistan because of the presence of infinite horizon and liquidity constraint. Waqas and Awan (2012) investigated the validity of Ricardian equivalence hypothesis in Pakistan using time series data from 1973 to 2010. The study utilized the ARDL co-integration approach in order to find out the short run and long run relationship among variables. Wald test is applied to check restrictions on REH. Result of Wald test rejects these restrictions and study found no evidence of Ricardian equivalence Hypothesis in Pakistan.

Saeed and Khan (2012) explored the existence of REH in Pakistan using time series data for the year 1972-2008. A simple consumption function is estimated. Johansen cointegration technique is applied after stationarity check to find out the long run relationship among variables. Error correction method (ECM) is used to check the short run relationship among variables. The paper concludes that no evidence is found in favour of Ricardian equivalence hypothesis. Oseni and Olomola (2013) tried to check the empirical existence of REH in Nigeria using time series data for the period 19812011. A model based on permanent income hypothesis (PIH) is estimated. Johansen cointegration approach is used for long run relationship and ECM is estimated for short run relationship. Results support the existence of REH in Nigeria with respect to the coefficient of government expenditure. According to the results, relationship between Government debt and wealth also supports the existence of REH, whereas signs of personal income and taxes do not support REH in Nigeria.

From literature it has been witnessed that there are mixed results regarding the validity of REH, some studies accepted this phenomenon while some rejected it. There is also evidence in the literature of partial validity of assumptions of REH.

\section{Materials and methods}

3.1. Variables and Data Sources:

Annual time series data from 1978 to 2013 has been used to explore the effects of different variables on private consumption (PC) and private saving (PS) in Pakistan. Variables included in the model are private saving (PS), private consumption (PC), tax Revenue (TR), government budget deficit (GBD), government debt (GD), disposable income $^{3}(\mathrm{DI})$ and wealth ${ }^{4}(\mathrm{~W})$. Data sources are IFS, hand book of statistics on Pakistan economy and different years of Economic surveys of Pakistan.

${ }^{3} \mathrm{~A}$ proxy variable of Gross National Income

${ }^{4}$ Proxy variable is calculated by adding Government debt and $M 2$ by following Waqas and

Awan (2011)

Sukkur IBA Journal of Management and Business | Volume 3 No. 2 July - December 2016 ○ Sukkur Institute of Business Administration 
The study utilized following equations; structural consumption and structural saving function, for empirical results

\section{a. Structural Consumption Function:}

We used structural consumption function that has been used by Waqas and Awan (2011) with certain modifications.

$$
P C=\alpha_{0}+\beta_{1} T R+\beta_{2} G D+\beta_{3} D I+\beta_{4} W+u .
$$

Where PC stands for Private consumption, TR indicates tax revenue, GD is government debt, DI indicates disposable income and W stands for wealth. Consumption function has following restrictions which must be fulfilled for the acceptance of REH.

$$
\beta_{1}=0, \quad \beta_{2}=0, \quad \beta_{4}=\beta_{2}
$$

$1^{\text {st }}$ two restrictions explain that tax revenue (TR) and government debt (GD) both must be equal to zero which affirms that private consumption is not affected by changes in TR and GD. While government debt and wealth must be equal which affirm that amount of consumers purchased bonds and government's deficit financing are the same.

\section{b. Structural Saving Function}

We used structural consumption function that has been used by Kazmi (1994) with certain modifications.

$$
P S=\alpha_{0}+\beta_{1} T R+\beta_{2} G B D+\beta_{3} G D+\beta_{4} D I+u .
$$

Where PS stands for private saving, TR indicates Tax revenue, GBD stands for Government budget deficit, GD indicates Government debt and DI indicates Disposable income. Saving function has following restrictions:

$$
\beta_{2}=\beta_{3}, \quad \beta_{2}+\beta_{3}=0, \beta_{1}+\beta_{4}=0
$$

The $1^{\text {st }}$ restriction states that government debt and government budget deficit must be equal which affirms that amount of government issued bonds and budget deficit is same. The $2^{\text {nd }}$ restriction explains addition of tax revenue and government debt must be equal to zero. The $3^{\text {rd }}$ restriction explains that addition of tax revenue and disposable income must also be equal to zero.

\section{Empirical Findings:}

Time series data is non-stationary in nature which provides spurious results. Therefore, it is necessary to check the stationarity of variables. This study used two unit root tests

Sukkur IBA Journal of Management and Business | Volume 3 No. 2 July - December 2016 @ Sukkur Institute of Business Administration 
to check the stationarity of variables; Augmented Dickey Fuller (ADF) and Kwiatkowski, Phillips, Schmidt, and Shin Test (KPSS).

Table 1: Unit root results

\begin{tabular}{|c|c|c|c|c|}
\hline Variables & \multicolumn{2}{|c|}{$\underline{\mathrm{ADF}}$} & \multicolumn{2}{|l|}{$\underline{\underline{K P S S}}$} \\
\hline \multicolumn{5}{|c|}{ Trend and Intercept } \\
\hline & Level & Difference & Level & Difference \\
\hline $\mathrm{PC}$ & -0.321563 & $-4.734473 *$ & $0.180230 *$ & $0.131579 * *$ \\
\hline PS & 2.243240 & $9.116222 *$ & 0.220388 & $0.168465^{*}$ \\
\hline TR & $4.975051 *$ & $-3.320362 * * *$ & $0.196124 *$ & $0.170207 *$ \\
\hline GBD & $5.169262 *$ & 3.078548 & $0.176096^{*}$ & $0.184458 *$ \\
\hline GD & 2.463822 & $-6.809577 *$ & $0.194967 *$ & $0.0705^{* * *}$ \\
\hline DI & $6.091870 *$ & $4.455183 *$ & $0.191130 *$ & $0.083689 * * *$ \\
\hline $\mathrm{W}$ & $4.041738 * *$ & -2.920203 & $0.203627^{*}$ & $0.167542 *$ \\
\hline Variables & $\mathrm{ADF}$ & & $\underline{\text { KPSS }}$ & \\
\hline \multicolumn{5}{|c|}{ Intercept } \\
\hline & Level & Difference & Level & Difference \\
\hline $\mathrm{PC}$ & 1.869660 & $-4.602997 *$ & $0.790286^{*}$ & $0.412153^{* *}$ \\
\hline PS & $4.464899 *$ & 0.292213 & $0.634945^{*}$ & $0.693458 *$ \\
\hline $\mathrm{TR}$ & $10.44711 *$ & 1.633731 & $0.698804 *$ & $0.599464 *$ \\
\hline GBD & $7.071057 *$ & $3.446997 * *$ & $0.597073^{*}$ & $0.541901 *$ \\
\hline GD & $4.912321^{*}$ & -0.954815 & $0.638045^{*}$ & $0.442346 * *$ \\
\hline DI & $6.991688 *$ & $8.228461 *$ & $0.604358 *$ & $0.229271 * * *$ \\
\hline $\mathrm{W}$ & $4.386865^{*}$ & -0.954815 & $0.622842 *$ & $0.571522 *$ \\
\hline
\end{tabular}

PC is private consumption; PS is private saving: DI is disposable income; TR is tax revenue; GBD is Government budget deficit; GD is Government debt and W stands for wealth. *shows the significance level at $1 \%$ and $* *$ shows at $5 \%$ and $* * *$ at $10 \%$ level. This is taken from Mankinon (1996) one-sided p-values.

Normally time series have trend and intercept, but this study estimated the stationarity test by using both situations: with trend and without trend. The results of ADF under trend and intercept show that TR, W, GBD and DI are stationary at level while PS, GD and PC are stationary at first difference. The result of KPSS test under trend and intercept shows all variables are stationary at level except PS, which is $I(1)$. The results of unit root tests explore that all the variables have different order of integration. Therefore, the study utilized the ARDL co-integration approach for both models.

\section{a. Structural consumption function:}

The study utilized the ARDL co-integration approach for structural consumption function in order to find out the short run and long run relationship among variables. 1 st step is to check the co-integration between variables.

Sukkur IBA Journal of Management and Business | Volume 3 No. 2 July - December 2016 @ Sukkur Institute of Business Administration 
Table 2: Result of bound test for co-integration

\begin{tabular}{lll}
\hline Variables & $\underline{\text { F-Statistics }}$ & Conclusion \\
\hline F(PC|GD,DI,TR,W) & $10.3359^{* * *}$ & Cointegration \\
F(GD|TR,DI,PC,W) & $24.7573^{* * *}$ & Cointegration \\
F(TR|GD,DI,PC,W) & $39.8470^{* * *}$ & Cointegration \\
F(DI|GD,TR,PC,W) & $3.1026 * *$ & No Cointegration \\
F(W|DI,GD,TR,PC) & $202.5745^{* * *}$ & Cointegration \\
\hline
\end{tabular}

Note: AIC and SBC were used for the lag length. * shows that the statistic lies below the lower bound, ** it falls within the lower and upper bounds and $* * *$ it presents outside the upper bound.

The results of Bound tests for co-integration show that there exists long run relationship among variables because F-statistics is higher than upper bound, which rejects the Null hypothesis which is No Co-integration.

After estimating bound test for co-integration, ECM is estimated to find out the short run relationship by selecting base on $\operatorname{SBC-ARDL~(1,1,1,0,~and~0).~ECM~explains~the~}$ speed of convergence toward equilibrium. Small value of error correction term shows low speed of convergence to equilibrium.

Table 3: Results of error correction model

\begin{tabular}{llll}
\hline \multicolumn{4}{l}{ Error Correction Representation for the Selected ARDL Model } \\
\hline \multicolumn{4}{l}{ ARDL(1,1,1,0,0) selected based on Schwarz Bayesian Criterion } \\
Variables & \multicolumn{1}{l}{ Coefficient } & & T-Ratio[Prob] \\
Constant & 261578.3 & & $1.6627[.108]$ \\
dTR & -2.0486 & & $-1.9544[.060]$ \\
dDI & -.15848 & $-3.6909[.001]$ & \\
dGD & .11038 & $.55126[.586]$ & \\
dW & -.13640 & $-.62214[.539]$ & \\
ECM(-1) & -.13840 & $-1.2832[.210]$ & \\
R-Squared & .78393 & R-Bar-Squared & .72791 \\
S.E. of Regression & 131237.8 & F-stat & $19.5917[.000]$ \\
DW-statistic & 1.8652 & &
\end{tabular}

Note: R-Squared and R-Bar-Squared measures refer to the dependent variable dPC and in cases, where the error correction model is highly restricted, these measures could become negative.

Results show that coefficient of ECM is negative and insignificant; hence equilibrium will diverge in case of any shock to independent variables. TR and DI show that they have significant effect on private consumption (PC) in the short run while GD and W provide in-significant results. The negative sign of TR and DI shows that they have inverse relationship with PC. OLS technique has been used to estimate consumption function. Wald test rejects all restrictions.

Sukkur IBA Journal of Management and Business | Volume 3 No. 2 July - December 2016 ๑ Sukkur Institute of Business Administration 
Table 4: Results of OLS technique

\begin{tabular}{llll}
\hline Variables & \multicolumn{1}{c}{ Coefficients } & t-value & \\
\hline Constant & 1483542 & 23.34893 & \\
$\Delta$ TR & -3.518880 & -2.012569 & \\
$\Delta$ GD & 0.959398 & 3.557664 & \\
$\Delta$ DI & 0.223289 & -3.271691 & \\
$\Delta \mathrm{W}$ & 0.691142 & 2.050832 & \\
$\beta 1=0, \quad \beta 2=0, \quad \beta 2=\beta 4$ & & \\
F-statistic $=42.85623[0.0000]$ & & \\
R-Square & 0.970189 & D.W & 0.709912 \\
SER & 249089.5 & F-Statistics & 252.2198 \\
Adjusted R-Square & 0.966342 & & \\
\hline
\end{tabular}

According to OLS results, there exist negative relationship between tax revenue and private consumption. While, private consumption is positively related with disposable income, wealth and government debt. Hence there is an absolute disagreement between our results and theory of REH. Therefore, REH does not hold good in Pakistan. Our results are in line with several Pakistan based studies that includes Kazmi and Shabbir (1992), (Waqas and Awan (2011), 2012)), and Saeed and Khan (2012).

\section{b. Structural saving function:}

The study also utilized the ARDL co-integration approach for structural saving function. The results of Bound tests for co-integration show that there exists long run relationship among variables because F-statistics is higher than upper bound, which rejects the Null hypothesis of No Co-integration.

Table 5: Result of bound test for co-integration

\begin{tabular}{lll}
\hline Variables & F-Statistics & Conclusion \\
\hline F(PS|GBD,GD,DI,TR) & $6.3597 * * *$ & Cointegration \\
F(GBD|GD,TR,DI,PS) & $15.7197 * * *$ & Cointegration \\
F(GD|GBD,TR,DI,PS) & $10.4915 * * *$ & Cointegration \\
F(TR|GD,GBD,DI,PS) & $16.7120 * * *$ & Cointegration \\
F(DI|GD,TR,GBD,PS) & $3.9738 * *$ & No Cointegration
\end{tabular}

Note: AIC and SBC were used for the lag length. * Indicates that the statistic lies below the lower bound, ** it falls within the lower and upper bounds and *** it lies outside the upper bound.

Table 6: Results of error correction model

Error Correction Representation for the Selected ARDL Model

ARDL $(1,0,1,0,1)$ selected based on Schwarz Bayesian Criterion Variables Coefficient T-Ratio[Prob]

Sukkur IBA Journal of Management and Business | Volume 3 No. 2 July - December 2016 @ Sukkur Institute of Business Administration 


\begin{tabular}{llll}
\hline Constant & -40654.6 & $-1.6586[.109]$ & \\
dTR & 1.6032 & $4.2928[.000]$ & \\
dDI & 0.084955 & $3.5179[.001]$ & \\
dGD & 0.041492 & $0.35286[.727]$ & \\
dGBD & -0.047665 & $-0.20068[.842]$ & \\
ECM(-1) & -0.74450 & $-5.1040[.000]$ & \\
R-Squared & 0.74882 & $\underline{\text { R-Bar-Squared }}$ & .68370 \\
S.E. of Regression & 90942.8 & $\underline{\text { F-stat }}$ & $16.0988[.000]$ \\
DW-statistic & 1.6108 & & \\
\hline
\end{tabular}

Note: R-Squared and R-Bar-Squared measures refer to the dependent variable dPS and in cases, where the error correction model is highly restricted, these measures could become negative.

ECM results shows that coefficient of ECM is negative and significant; hence equilibrium will converge in case of any shock to independent variables. Tax revenue and disposable income show that they have significant effect on private saving in the short run while, government debt and government budget deficit provide insignificant results. The positive sign of tax revenue and disposable income show that as the tax revenue and disposable income increase the private saving also increases. Tax revenue and disposable income have positive relationship with private saving. The OLS technique has been used to estimate saving function. The result of Wald test partially rejects the restrictions of REH.

Table 7: Results of OLS technique

\begin{tabular}{|c|c|c|c|}
\hline Variables & Coefficients & t-value & \\
\hline Constant & 216.6789 & $.0067847[.995$ & \\
\hline D TR & 1.6617 & $3.3813[.002]$ & \\
\hline D GBD & .48425 & $1.6765[.104]$ & \\
\hline D GD & -.26684 & $-1.8012[.081]$ & \\
\hline D DI & .072830 & $3.3900[.002]$ & \\
\hline \multicolumn{4}{|c|}{$\begin{array}{l}\beta 2=\beta 3, \quad \beta 1+\beta 3=0, \quad \beta 1+\beta 4=0 \\
\text { F-statistic }=16.44059[0.0000]\end{array}$} \\
\hline R-Square & .96572 & D.W & 1.4851 \\
\hline SER & 130010.0 & F-Statistics & $218.3333[.000]$ \\
\hline Adjusted R-Square & .96130 & & \\
\hline
\end{tabular}

According to OLS results, there exist negative relationship between government debt and private saving. Private saving is positively related with disposable income, tax revenue, and government budget deficit. There is partial negation between our results and theory of REH. Therefore, REH is also rejected in case of saving function. Our results are in line with (Kazmi (1995); Kazmi and Bilquees (1993); Kazmi and Shabbir (1992)) that also partially rejected the REH in case of Pakistan 


\section{Conclusion and policy implication}

We checked the validity of Ricardian equivalence hypothesis in Pakistan by using time series data from 1978 to 2013. Two functions have been specified to investigate the existence of REH; consumption function and saving function. The results of unit root tests guide us to utilize the ARDL co-integration approach for both models to find out the short run and the long run relationship among variables. The results verify the existence of long run relationship among variables. Both functions are estimated using OLS technique. Wald test completely rejects the restriction on consumption function and partially rejects the restrictions on saving function. Thus, the study found no evidence of Ricardian Equivalence Hypothesis in Pakistan. The study confirms that fiscal policy is effective in Pakistan because consumers increase private consumption due to tax cut. Hence fiscal policy can be used as a major stabilization policy. Furthermore, there is a need to widen the tax base instead of increasing tax rate.

\section{References}

Barro, R. J. (1974). Are government bonds net wealth? Journal of political economy, 82(6), 1095-1117.

Bird, R. M., \& Zolt, E. M. (2003). Introduction to tax policy design and development. Prepared for a course on "Practical Issues of Tax Policy in Developing Countries," World Bank, 28, 05-22.

Cunningham, J. P., \& Harberger, A. C. (2005). MICROECONOMIC TESTS OF RICARDIAN EQUIVALENCE.

Dem, A., Mihailovici, G., \& Gao, H. (2001). Inflation and hyperinflation in the 20th century: Causes and patterns. Columbia University, School of International and Public Affairs, http://www. itulip. com/Select/hyperinflation. pdf,[last accessed 20.02. 2014].

Di Laurea, D., \& Ricciuti, R. (2002). Departures from Ricardian Equivalence: An Experimental Evaluation.

Gumus, E. (2003). Crowding-Out Hypothesis versus Ricardian Equivalence Proposition: Evidence from Literature.

Kazmi, A. A. (1995). An econometric estimation of tax-discounting in Pakistan. The Pakistan Development Review, 34(4), 1067-1077.

Kazmi, A. A., \& Bilquees, F. (1993). National Savings Rates of India and Pakistan: A Macroeconometric Analysis [with Comments]. The Pakistan Development Review, 32(4), 1313-1324.

Kazmi, A. A., \& Shabbir, T. (1992). Ricardian Equivalence: Some Macro-econometric Tests for Pakistan [with comments]. The Pakistan Development Review, 31(4), 743-758.

Malengier, G., \& Pozzi, L. (2004). Examining Ricardian Equivalence by estimating and bootstrapping a nonlinear dynamic panel model. Money Macro and Finance Research Group Confrence.

Sukkur IBA Journal of Management and Business | Volume 3 No. 2 July - December 2016 ○ Sukkur Institute of Business Administration 
Oseni, I., \& Olomola, P. (2013). Testing the validity of Ricardian Equivalence Hypothesis in Nigeria. International Journal of Business and Economic Research, 1(1), 164-174.

Ricardo, D. (1817). On foreign trade. Principles of political economy and taxation.

Saeed, S., \& Khan, M. A. (2012). Ricardian Equivalence Hypothesis and Budgetary Deficits: The Case of Pakistan 1972-2008. Interdisciplinary Journal of Contemporary Research in Business, 3(9).

Tcherneva, P. R. (2011). Fiscal policy effectiveness: Lessons from the Great Recession.

Waqas, M., \& Awan, M. S. (2011). Are Pakistani consumer Ricardian? Economic and Business Review, 13(3), 161-177.

Waqas, M., \& Awan, M. S. (2012). Exchange Rate, Interest Rate and Ricardian Equivalence Evidence from Pakistan. The Romanian Economic Journal, 15(46), 249-270.

Sukkur IBA Journal of Management and Business | Volume 3 No. 2 July - December 2016 @ Sukkur Institute of Business Administration 